\title{
Адмиттанс МДП-структур на основе пентацена с двухслойным диэлектриком $\mathrm{SiO}_{2}-\mathrm{Al}_{2} \mathrm{O}_{3}$
}

\author{
А.В. Войцеховский, С.Н. Несмелов, С.М. Дзядух, Т.Н. Копылова, К.М. Дегтяренко \\ Национальный исследовательский Томский государственный университет,
} 634050, Томск, пр. Ленина, 36

DOI 10.34077/RCSP2021-147

Органо-неорганические системы актуальны из-за перспектив создания на их основе приборов опто, наноэлектроники и нановольтаики с расширенными функциональными возможностями [1]. Для получения детальной информации о свойствах органо-неорганических систем необходимо проведение комплексных исследований процессов в таких системах, что возможно при использовании различных экспериментальных методик. Простым и информативным методом изучения органо-неорганических систем является измерения адмиттанса (или импеданса) в различных условиях $[2,3]$.

При разработке новых экспериментальных методик исследования органо-неорганических систем удобно использование структур на основе органических пленок пентацена, который может использоваться в качестве модельного материала из-за его широкого применения в тонкопленочных транзисторах, солнечных элементах и устройствах памяти. В приборах на основе пентацена часто используются диэлектрические пленки $\mathrm{SiO}_{2}$, но актуальной остается разработка других диэлектрических покрытий. В докладе приводятся некоторые результаты исследования в широком диапазоне условий адмиттанса МДП-структур на основе пентацена с двухслойным диэлектриком $\mathrm{SiO}_{2}-$ $\mathrm{Al}_{2} \mathrm{O}_{3}$ и обратными контактами, сформированными из различных металлов ( $\left.\mathrm{Au}, \mathrm{Al}, \mathrm{In}, \mathrm{Ag}\right)$. Для исследований создавались МДП-структуры на основе органического полупроводника пентацена: с двухслойным диэлектриком $\mathrm{SiO}_{2}-\mathrm{Al}_{2} \mathrm{O}_{3}$. На поверхность $\mathrm{SiO}_{2}$ методом плазменного атомно-слоевого осаждения наносился слой $\mathrm{Al}_{2} \mathrm{O}_{3}$ толщиной около 90 нм. Перед формированием слоя пентацена для очистки поверхности структуры промывались в изопропиловом спирте с последующей обработкой в кислородной плазме. Органические пленки пентацена толщиной около 50 нм наносились методом термовакуумного напыления. Обратные контакты из различных металлов (Au, Al, In, Ag - образцы №№ 1-4, соответственно) формировались при помощи термического напыления в вакууме через маску с отверстиями. Измерения проводились при помощи автоматизированной установки для спектроскопии адмиттанса наногетероструктур на основе измерителя иммитанса Agilent E4980A и неоптического криостата Јanis. Установка позволяла измерять зависимости адмиттанса от температуры (8-300 К), частоты (1-2000 кГц), напряжения смещения (от -40 до 40 В).

По наклону ВФХ в режиме обеднения находилась концентрация дырок в пленке пентацена (анализ Мотта-Шоттки). Определенная концентрации дырок оказались достаточно большой $(3-30) \times 10^{17} \mathrm{~cm}^{-3}$, что может быть объяснено в рамках модели непреднамеренного легирования. Зная концентрацию дырок в пентацене, можно определить емкость и напряжение плоских зон при различных направлениях развертки напряжения. Плотность медленных состояний при емкости плоских зон оказалась минимальна $\left(2.2 \times 10^{12} \mathrm{~cm}^{-2}\right)$ для структуры № 3 (Pen-In), а максимальна $\left(4.5 \times 10^{12} \mathrm{~cm}^{-2}\right)$ для структуры № 1 (Pen-Au). Экспериментальные зависимости действительной и мнимой частей импеданса для образца с обратными контактами из различных материалов, были измерены при температуре $300 \mathrm{~K}$ и смещении -30 В. Предложена эквивалентная схема, характеризующая свойства диэлектрика, области пространственного заряда, квазинейтрального объема и обратного контакта. Для различных образцов найдены зависимости значений элементов эквивалентной схемы от напряжения смещения и температуры. Измерения импеданса изготовленных структур использовались также для изучения дефектов на границе раздела и в объеме пентацена. Для образца на основе пентацена с золотом обнаружен уровень поверхностных состояний на границе между пентаценом и диэлектриком $\mathrm{SiO}_{2-}$ $\mathrm{Al}_{2} \mathrm{O}_{3}$ с плотностью $1.5 \times 10^{11} \mathrm{~cm}^{-2}$, и временем перезарядки - около 3.2 мкс. Для образцов 1 и 4 обнаружены ловушки в объеме органической пленки пентацена [3].

Исследование выполнено при финансовой поддержке РФФИ и Администрации Томской области в рамках научного проекта № 18-43-700005.

\section{Лumepamypa}

[1] S.S. Sun, L.R. Dalton, Introduction to organic electronic and optoelectronic materials and devices, Taylor \& Francis, Boca Raton (2016).

[2] A.V. Voitsekhovskii et al., Phys. Stat. Sol. A, 1900847 (2020).

[3] A.V. Voitsekhovskii et al., Thin Solid Films, 692, 137622 (2020). 